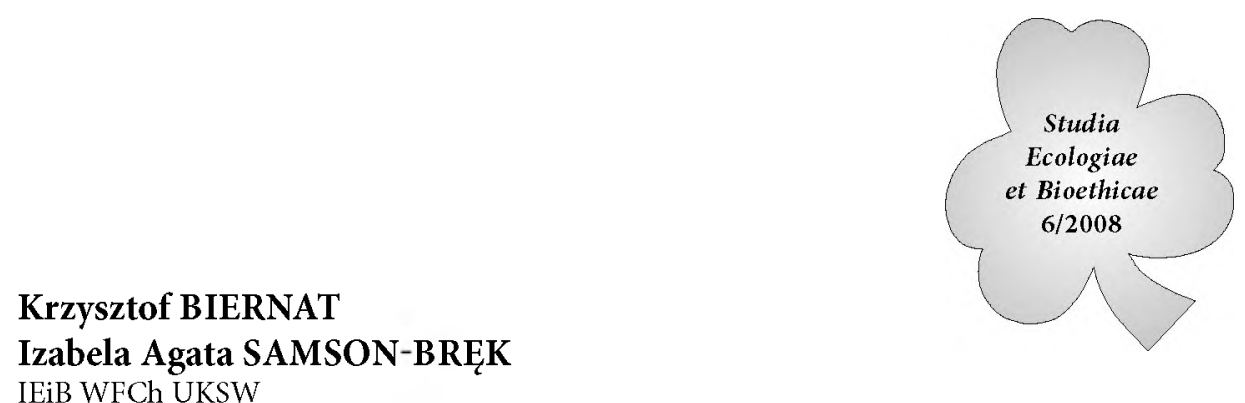

\title{
Wodór - paliwo przyszłości
}

\section{Wprowadzenie}

Na obecnym poziomie rozwoju cywilizacyjnego pojawiają się nowe problemy związane z dostępnością źródeł energii. Obecnie potrzeby energetyczne zaspakajane są w głównej mierze przez paliwa kopalne. Dostępne rezerwy ropy nie są jednoznaczne i do końca zdefiniowane zarówno ilościowa jak i geograficznie. Istnieją nowe rezerwy, ale w większości ich eksploatacja nie jest opłacalna, gdyż znajdują się zbyt głęboko. Na tym tle bezpieczeństwo energetyczne UE sprowadza się nie tylko do kwestii zmniejszenia uzależnienia od importu, ale także na podjęcie działań w celu dywersyfikacji źródeł energii i technologii.

Poza tym energia uzyskana z paliw kopalnych powoduje znaczne pogorszenie stanu środowiska naturalnego, przyczyniając się w głównej mierz do powstania efektu cieplarnianego.

W świetle powyższych obaw i zagrożeń pojawia się zainteresowanie wodorem, który może stanowić alternatywne, wobec paliw kopalnych, źródło energii oraz przyczynić się do poprawy stanu środowiska dzięki temu, że głównym produktem jego spalania jest woda.

\section{Technologie wytwarzania wodoru do celów energetycznych}

Obecnie w wielu państwach na świecie trwają badania nad technologiami wodorowymi oraz powstają różne programy mające na celu przetestowanie w warunkach praktycznych funkcjonowania wodoru jako nośnika energii. Również w Polsce wzrasta zainteresowanie technologią wodorową, czego wyrazem jest powstanie Polskiej Platformy \echnologicznej Wodoru i Ogniw Paliwowych. W polskich warunkach najbardziej prawdopodobny jest rozwój technologii produkcji wodoru $z$ węgla metodą podziemnego zgazowania. Polska, ze względu na posiadane pokłady węgla, może stać się zapleczem surowcowym dla produkcji wodoru w Europie. Rozwój polskiej gospodarki wodorowej powinien przebiegać jednak w pełnej współpracy górnictwa węglowego z sektorem energetycznym. 
Wodór ze względu na swoje właściwości z punktu widzenia paliwa silnikowego wyróżnia się spośród innych, stosowanych obecnie paliw. Do właściwości tych należą przede wszystkim duże ciepło spalania, szerokie granice palności, małą energię zapłonu, wysoką temperaturę samozapłonu, wysoką prędkość spalania, dużą dyfuzyjność, małą odległość gaszenia od ścianki, bardzo małą gęstość, dużą objętość gazowego wodoru w mieszance stechiometrycznej silnikowych porównaniu z benzyną czy metanem (tabela 1 ).

Tabela 1. Wtaściwości wodoru, benzyny i metanu jako paliw silnikowych

\begin{tabular}{|c|l|c|c|c|}
\hline Lp. & \multicolumn{1}{|c|}{ Właściwość } & Wodór & Benzyna & Metan \\
\hline 1. & Masa molekularna & 2,02 & 91,40 & 16,03 \\
\hline 2. & Ciepło spalania, MJ/kg & 120,1 & 43,4 & 49,8 \\
\hline 3. & $\begin{array}{l}\text { Mieszanina stechiometryczna, masa } \\
\text { powietrza/masa paliwa }\end{array}$ & 34,3 & 14,5 & 17,4 \\
\hline 4. & $\begin{array}{l}\text { Skład stechiometryczny w powietrzu; \% } \\
\text { obj. }\end{array}$ & 29,53 & 1,76 & 9,48 \\
\hline 5. & Liczba oktanowa LOB & 130 & 91,100 & 110 \\
\hline 6. & Granica zapalności w powietrzu; \% obj. & $4,0,75$ & $1,0,7,6$ & $5,3-15,0$ \\
\hline 7. & Minimalna energia zapłonu; mJ & 0,02 & 0,24 & 0,29 \\
\hline 8. & \emperatura zapłonu, K & 858 & 501,744 & 813 \\
\hline 9. & $\begin{array}{l}\text { Prędkość spalania w powietrzu w warun- } \\
\text { kach normalnych; m/s }\end{array}$ & $0,265,0,235$ & $0,37,0,43$ & $0,37,0,45$ \\
\hline 10. & $\begin{array}{l}\text { Promieniowanie energii termicznej } \\
\text { płomienia do otoczenia; \% }\end{array}$ & 17,25 & 30,42 & 23,33 \\
\hline 11. & Dyfuzyjność w powietrzu, cm2/s & 0,63 & 0,08 & 0,20 \\
\hline 12. & $\begin{array}{l}\text { Odległość gaszenia w powietrzu w wa- } \\
\text { runkach normalnych; cm }\end{array}$ & 0,064 & 0,200 & 0,203 \\
\hline
\end{tabular}

Wodór, jako paliwo silnikowe może być wytwarzany na skalę przemysłową między innymi za pomocą elektrolizy. Elektroliza wody jest jedną z najprostszych metod otrzymywania wodoru. Jest to proces rozkładu wody prądem elektrycznym w celu otrzymania wodoru i tlenu. Ponieważ czysta woda praktycznie nie przewodzi prądu elektrycznego jako elektrolit stosuje się rozcieńczony roztwór kwasu siarkowego lub wodorotlenku sodowego. Ogólna reakcja elektrolizy wody przebiega wg równania:

$$
2 \mathrm{H}_{2} \mathrm{O} \rightarrow 2 \mathrm{H}_{2} \mathrm{O}_{2}
$$

Proces elektrolizy jest wydajny, a pierwiastek powstały podczas tego procesu cechuje się dużą czystością dochodzącą do 99,9\%. Ilość energii otrzymana podczas procesu elektrolizy wody jest dużo niższa niż energia powstała ze spalania otrzymanego w wyniku tego procesu wodoru. Porównując sprawność wytwarzanego wodoru w procesie elektrolizy, która jest na poziomie $38-40 \%$ przy założe- 
niu, że warunki są optymalne oraz $25-28 \%$ w rzeczywistości z $45 \%$ sprawnością energii elektrycznej pochodzącej z elektrowni cieplnej wynika, że elektroliza jest procesem mało sprawnym energetycznie. Na tym tle atrakcyjne staje się zastąpienie energii elektrycznej energią cieplną pochodzącą ze źródeł pierwotnych w procesie elektrolizy wysokotemperaturowej. Wówczas koszty produkcji wodoru ulegają obniżeniu, a efektywność energetyczna wzrasta (tabela 2).

Tabela 2. Szacunkowy koszt produkcji wodoru

\begin{tabular}{|c|c|c|c|c|c|}
\hline \multirow{2}{*}{ Surowiec } & \multirow{2}{*}{$\begin{array}{l}\text { Sprawność } \\
\text { termiczna }\end{array}$} & \multirow{2}{*}{$\begin{array}{c}\text { Cena } \\
\text { surowca }\end{array}$} & \multicolumn{2}{|c|}{$\begin{array}{l}\text { Koszt instalacji } \\
{[\mathrm{DM} / \mathrm{GJ}]}\end{array}$} & \multirow{2}{*}{$\begin{array}{c}\text { Koszt całkowity } \\
{[\mathrm{DM} / \mathrm{GJ}]}\end{array}$} \\
\hline & & & $\mathrm{DM} / \mathrm{kWc}$ & $\mathrm{DM} / \mathrm{GJ}$ & \\
\hline $\begin{array}{l}\text { Elektroliza (elektrolizery } \\
\text { tradycyjne) }\end{array}$ & 0,75 & 0,12 & 1600 & 22,0 & 65 \\
\hline \multirow[t]{3}{*}{$\begin{array}{l}\text { Elektroliza (elektrolizery } \\
\text { nowej generacji) }\end{array}$} & 0,92 & 0,12 & 1380 & 15,4 & 52 \\
\hline & 0,90 & 0,09 & 1300 & 14,7 & 43 \\
\hline & 0,88 & 0,06 & 1220 & 13,1 & 12 \\
\hline
\end{tabular}

Kolejną metodą, dzięki której możliwe jest wytwarzanie wodoru jest zgazowanie węgla. Jest to metoda, która jako pierwsza służyła do produkcji gazów bogatych w wodór. Gazyfikacja węgla polega na konwersji stałego materiału węglowego na gaz. Reakcje przebiegające podczas zgazowani węgla przedstawiają się następująco:

$$
\begin{gathered}
\mathrm{C}+\mathrm{H}_{2} \mathrm{O} \leftrightarrow \mathrm{CO}+\mathrm{H}_{2}, \Delta \mathrm{H}=118,2 \mathrm{~kJ} / \mathrm{mol}, \\
\mathrm{C}+\mathrm{CO}_{2} \leftrightarrow 2 \mathrm{CO}, \Delta \mathrm{H}=160,9 \mathrm{~kJ} / \mathrm{mol}, \\
2 \mathrm{C}+\mathrm{O}_{2} \leftrightarrow 2 \mathrm{CO}_{2}, \Delta \mathrm{H}=-221 \mathrm{~kJ} / \mathrm{mol}, \\
\mathrm{C}+\mathrm{O}_{2} \leftrightarrow 2 \mathrm{CO}_{2}, \Delta \mathrm{H}=-409,7 \mathrm{~kJ} / \mathrm{mol}, \\
\mathrm{C}+2 \mathrm{H}_{2} \leftrightarrow \mathrm{CH}_{4}, \Delta \mathrm{H}=-77,9 \mathrm{~kJ} / \mathrm{mol}, \\
2 \mathrm{CO}+\mathrm{O}_{2} \leftrightarrow 2 \mathrm{CO}_{2}, \Delta \mathrm{H}=-570,6 \mathrm{~kJ} / \mathrm{mol}, \\
\mathrm{CO}+\mathrm{H}_{2} \mathrm{O} \leftrightarrow \mathrm{CO}_{2}+\mathrm{H}_{2}, \Delta \mathrm{H}=-42,7 \mathrm{~kJ} / \mathrm{mol} .
\end{gathered}
$$

Szczególnym przypadkiem zgazowania węgla jest przeprowadzenie tego procesu pod ziemią. 区echnologia podziemnego zgazowania węgla (rys. 1) powstała w 1867 roku. Wilhelm Siemens zaproponował zgazowanie węgla pod ziemią oraz odprowadzanie powstałych gazów siecią rurociągów. Podczas spalania węgla przy niedoborze tlenu głównym produktem spalania jest tlenek węgla (II). Po wydobyciu na powierzchnię tlenek węgla może być łatwo konwertowany parą wodną zgodnie $\mathrm{z}$ reakcją:

$$
\mathrm{CO}+\mathrm{H}_{2} \mathrm{O} \rightarrow \mathrm{CO}_{2}+\mathrm{H}_{2}, \Delta \mathrm{H}=-42 \mathrm{~kJ} / \mathrm{mol}
$$




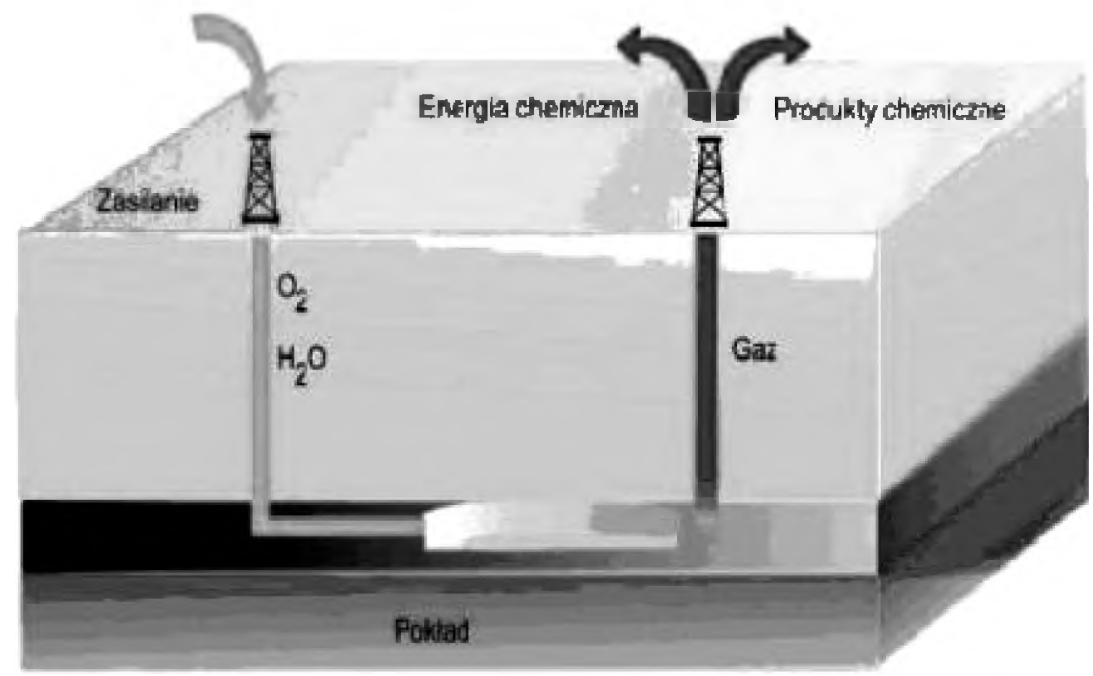

Rys. 1 Idea procesu podziemnego zgazowania wegla

Najważniejszym procesem wytwarzania wodoru, z punktu widzenia ochrony środowiska, jest zgazowanie biomasy. Biomasa ze względu na powszechność występowania może stać się zastępczym źródłem energii w stosunku do paliw kopalnych. Ze względu na skład chemiczny wyróżnia się 3 rodzaje biomasy, z której może być produkowany wodór:

- biomasa zawierająca cukry proste i dicukry (np. buraki cukrowe),

- biomasa skrobiowa (np. ziemniaki),

- biomasa lignocelulozowa (np. trawy, drewno).

\radycyjne zgazowanie biomasy przebiega $w$ temperaturze $600^{\circ} \mathrm{C} w$ obecności tlenu, powietrza lub pary wodnej. Wilgotność biomasy, która będzie poddana procesowi zgazowania nie powinna przekraczać 10-15\% dlatego też zgazowanie poprzedza szereg procesów związanych $z$ odpowiednim przygotowaniem biomasy. Podczas zgazowania biomasy zachodzi szereg różych procesów:

1. Częściowe utlenienie węgla zawartego w biomasie:

$$
\mathrm{C}+1 / 2 \mathrm{O}_{2} \rightarrow \mathrm{CO}, \Delta \mathrm{H}=-111 \mathrm{~kJ} / \mathrm{mol}
$$

2. Całkowite utlenianie węgla zawartego w biomasie:

$$
\mathrm{C}+\mathrm{O}_{2} \rightarrow \mathrm{CO}_{2}, \Delta \mathrm{H}=-394 \mathrm{~kJ} / \mathrm{mol}
$$

3. Endogeniczna reakcja wytwarzania gazu wodnego:

$$
\mathrm{C}+\mathrm{H}_{2} \mathrm{O} \rightarrow \mathrm{CO}+\mathrm{H}_{2}, \Delta \mathrm{H}=131 \mathrm{~kJ} / \mathrm{mol}
$$

4. Reakcja konwersji tlenku węgla parą wodną: 


$$
\mathrm{CO}+\mathrm{H}_{2} \mathrm{O} \rightarrow \mathrm{CO}_{2}+\mathrm{H}_{2}, \Delta \mathrm{H}=-41 \mathrm{~kJ} / \mathrm{mol}
$$

5. Reakcja metalizacji:

$$
\mathrm{CO}+2 \mathrm{H}_{2} \rightarrow \mathrm{CH}_{4}+\mathrm{H}_{2} \mathrm{O}, \Delta \mathrm{H}=-206 \mathrm{~kJ} / \mathrm{mol}
$$

W wyniku zgazowania biomasy otrzymywany jest gaz, który stanowi mieszaninę wodoru, tlenku węgla, ditlenku węgla, metanu i węglowodorów. Powstały gaz jest poddawany procesowi reformingu parowego w wyniku, którego powstaje gaz syntezowy służący do produkcji wodoru.

Biowodór można również otrzymać na drodze jej hydrotermalnego zgazowania. Proces ten jest prowadzony pod ciśnieniem i przy użyciu pary wodnej będącej w warunkach nadkrytycznych (temperatura przekracza wartość $374,2^{\circ} \mathrm{C}$, zaś ciśnienie $22,05 \mathrm{MPa}$ ). W procesie tym można otrzymać wodór bezpośrednio $z$ biomasy drzewnej w reakcji $\mathrm{z}$ wodą. Cechą charakterystyczną tego procesu jest to, że wodór można otrzymać z silnie zawodnionych nośników energii. Istotą tego procesu jest to, że substancje organiczne mogą reagować $\mathrm{z}$ wodą $\mathrm{w}$ stanie nadkrytycznym bez udziału tlenu.

Przykładem procesu hydrotermalnego zgazowania biomasy może być reakcja glukozy $\mathrm{z}$ wodą $\mathrm{w}$ warunkach nadkrytycznych:

$$
\mathrm{C}_{6} \mathrm{H}_{12} \mathrm{O}_{2}+6 \mathrm{H}_{2} \mathrm{O} \rightarrow 6 \mathrm{CO}_{2}+12 \mathrm{H}_{2}, \Delta \mathrm{H}==37,9 \mathrm{~kJ} / \mathrm{mol}
$$

Surowcami do procesów hydrotermalnego zgazowania biomasy mogą być zarówno odpady z przemysłu leśnego, rolno-spożywczego, odpady komunalne oraz osady z oczyszczalni ścieków. Stopień przemiany surowca wynosi ok. 90\% całkowitej masy.

Ciekawą propozycją otrzymywania biowodou jest konwersja odpadów z przemysłu mleczarskiego. Ścieki z przemysłu rolno-spożywczego są dobrym surowcem do produkcji bioenergii ze względu na znaczne ilości łatwo rozkładalnych zanieczyszczeń organicznych. Na szczególna uwagę zasługuje serwatka będąca produktem ubocznym powstającym przy produkcji serów twardych i twarogów. W związku z tym, że serwatka stanowi doskonały substrat fermentacyjny, może stać się surowcem do produkcji wysokoenergetycznych paliw gazowych.

Układ technologiczny, w którym serwatka byłaby wykorzystywana do produkcji wodoru jest układem trójstopniowym. Wydajność produkcji wodoru w procesie fermentacji zależy między innymi od odczynu środowiska ściekowego (pH 5,0-6,0), czasu retencji (nie dłuższy niż $12 \mathrm{~h}$ ), ciśnienia parcjalnego gazowych produktów fermentacji (nie wyższe niż $60 \mathrm{~Pa}$ ) oraz rodzaju substratu.

\section{Magazynowanie i dystrybucja wodoru}

$\mathrm{Na}$ drodze do powszechnego zastosowania wodoru jako paliwa silnikowego jedną z przeszkód stanowi magazynowanie tego gazu. W zakresie magazynowania wodoru od dawna trwają badania nad odpowiednimi sposobami przechowy- 
wania wodoru, które będą spełniały wymogi bezpieczeństwa oraz materiałami, dzięki którym to bezpieczeństwo będzie zapewnione oraz które będą odporne na niszczenie wodorowe.

Najbardziej rozpowszechniona jest magazynowanie wodoru w stanie sprężonego gazu oraz w postaci gazu skroplonego. Jest to związane między innymi z późniejszym zastosowaniem wodoru jako paliwa samochodowego. Pierwszy sposób jest najbardziej rozpowszechnioną metodą przechowywania wodoru. Jednak mała gęstość wodoru powoduje, że nawet przy odpowiednio dużym ciśnieniu można zgromadzić jedynie niewielką ilość tego gazu. Aby wodór pozostał w stanie sprężonym powinien być przechowywany w temperaturze ok. $298 \mathrm{~K}$ i ciśnieniu od 8 do $16 \mathrm{MPa}$. 区akie warunki przechowywania wodoru wymagają zastosowania zbiorników o wysokiej wytrzymałości, co podyktowane jest względami bezpieczeństwa. Aby zbiornik został uznany za bezpieczny powinien wytrzymać bardzo wysokie ciśnienia. Przewiduje się, że jeśli badania nad odpowiednimi materiałami, które będą w stanie wytrzymać takie warunki powiodą się, to jedno tankowanie przy ciśnieniu 700 barów (70 MPa) dawać będzie w zbiorniku 150- litrowym $7 \mathrm{~kg}$ wodoru. Jest to ilość, która powinna wystarczyć na przejazd odcinka o długości $550-650 \mathrm{~km}$. \akie badania są obecnie prowadzone w ramach unijnego projektu "StorHy" (Storage of Hydrogen) na Wydziale Materiałoznawstwa i Mechaniki 『echnicznej Politechniki Wrocławskiej. Celem tych badań jest opracowanie metod bezpiecznego i efektywnego gromadzenia wodoru, alternatywnego dla ropy paliwa przyszłości.

Druga metoda jest bardzo kosztowna (tabela 3), co związane jest $\mathrm{z}$ koniecznością dostarczenia dużych ilości energii w celu skroplenia gazu oraz budową zbiorników, które muszą posiadać odpowiednich izolację utrzymując odpowiednią temperaturę wewnątrz zbiornika. Do izolacji zbiorników używa się zazwyczaj ciekłego azotu. Dobowe ubytki wodoru w wyniku parowania przy zastosowaniu tej metody magazynowania wynoszą ok. $0,1 \%$. Aby zmniejszyć straty wodoru można zastosować np. izolację próżniową, przy której dobowe straty spowodowane parowaniem wynoszą zaledwie $0,01 \%$.

Tabela 3. Koszty jednostkowe magazynowania wodoru

\begin{tabular}{|c|c|c|c|c|}
\hline \multirow{2}{*}{$\begin{array}{c}\text { Magazyn wo- } \\
\text { doru }\end{array}$} & \multicolumn{4}{|c|}{ Koszt magazynowania wodoru w DM/Kw. Przy czasie wykorzystania } \\
od 500 do 2500 h/a
\end{tabular}




\begin{tabular}{|c|c|c|c|c|}
\hline $\begin{array}{c}\text { Naziemy zbior- } \\
\text { nik ciśnieniowy }\end{array}$ & $0,050-0,030$ & $0,065-0,055$ & $0,175-0,165$ & wysokie \\
\hline Wodorki metali & $0,050-0,045$ & $0,075-0,085$ & $0,250-0,200$ & wysokie \\
\hline Wodór ciekły & $0,175-0,060$ & $0,175-0,065$ & $0,180-0,070$ & wysokie \\
\hline
\end{tabular}

Ciekawym i innowacyjnym sposobem na magazynowanie wodoru jest wykorzystanie tzw. mikro-sfer. Przechowywanie wodoru w mikro-sferach polega na zastosowaniu szklanych, wydrążonych kuleczek, tzw. mikro- sfer. Mają one średnicę ok. 50-100 $\mu \mathrm{m}$ i grubość ścianek ok. $5 \mu \mathrm{m}$. Przenikalność wodoru przez szkło jest ściśle uzależniona od temperatury, dlatego kulki można napełniać w odpowiedniej temperaturze i pod odpowiednim ciśnieniem. Jednak kulki poddawane przez dłuższy czas oddziaływaniu wysokich ciśnień ulegają korozji naprężeniowej i nie nadają się do ponownego wykorzystania. W związku z tym ten sposób przechowywania wodoru może nie mieć większego znaczenia w przyszłości.

Najbardziej korzystną metodą magazynowania wodoru jest zastosowanie wodorków metali. Wodorkami nazywamy związki wodoru z innymi pierwiastkami. Wodór może wchodzić w związki z metalami lub ich stopami, a następnie dysocjować, co stwarza możliwości jego magazynowania. Zaletą wodorków jest duża gęstość magazynowanego wodoru, duża trwałość oraz możliwość wielokrotnej dysocjacji i akumulacji wodoru.

Wodorować można metodami chemicznymi i fizycznymi, poprzez umieszczenie próbki w atmosferze wodoru w odpowiedniej temperaturze i ciśnieniu. Pochłanianie wodoru polega na rozerwaniu cząsteczki wodoru w momencie jej zblizenia do powierzchni metalu. Odbywa się to dzięki oddziaływaniu z potencjałem powierzchniowym metalu. Jednocześnie następuje włączenie elektronów atomu wodoru do pasma elektronowego metalu, a jony wodoru jako dodatnio naładowane protony rozpoczynają dyfuzję w sieci metalu. Dyfuzja jonów wodoru następuje pomiędzy miejscami międzywęzłowymi struktury. Prędkość dyfuzji jest ściśle uzależniona od temperatury.

Opracowanie odpowiednich, najbardziej uzasadnionych ekonomicznic metod wytwarzania i magazynowania wodoru nie wystarczy jednak, aby gaz ten był wykorzystywany powszechnie jako paliwo silnikowe. Droga do zastosowania wodoru w silnikach samochodowych w praktyce jest jeszcze długa, gdyż wiąże się ze stworzeniem podstaw technicznych do zasilania konwencjonalnych silników jak również odpowiedniej infrastruktury. 


\section{Wodór jako paliwo silnikowe}

Wodór może zasilać zarówno silniki o zapłonie iskrowym jak i o zapłonie samoczynnym. Silniki o zapłonie samoczynnym mają na ogół duży stopień sprężania, który wymaga zmniejszenia, zaśs silniki z zapłonem iskrowym przeciwnie - mają zbyt mały stopień sprężania i wymaga on zwiększenia w celu uzyskania odpowiedniej efektywności procesu spalania. Wodór może być wykorzystywany również do zasilania silników dwupaliwowych, zarówno benzynowych, jak i o zapłonie samoczynnym. Silniki przystosowane do zasilania wodorem nie zapewniają optymalnych charakterystyk jego parametrów roboczych w stosunku do silników fabrycznie skonstruowanych w tym zakresie. Moc silnika zasilanego wodorem jest mniejsza o ok. $40 \%$ w porównaniu z silnikami seryjnymi, co wynika z mniejszej o $35 \%$ wartości opałowej mieszanki zgromadzonej w komorze spalania, jak również z faktu, że dwupaliwowego zasilania nie można wysterować na optymalne spalanie wodoru.

Wodór zasilający silniki spalinowe może występować zarównow postaci gazowej, jak również w postaci skroplonego wodoru. Zbiorniki, w których znajduje się paliwo wodorowe są wykonane z materiałów, które znacznie zwiększają ich masę, co powoduje, że zbiorniki takie są zazwyczaj stosowane w dużych pojazdach takich jak autobusy. Wprowadza się jednak nowe technologie, które przewidują konstruowanie zbiorników paliwowych ze stopów aluminium i włókien węglowych, co zapewniłoby im lekkość i możliwość zastosowania w pojazdach o mniejszej masie.

Konstrukcja silnika zasilanego wodorem zależy ściśle od stanu (gaz sprężony lub skroplony), w jakim paliwo to będzie dostarczane do pojazdu. Silniki zasilane ciekłym wodorem posiadają bardzo ostre wymagania, co do izolacji zbiornika. Związane jest to $\mathrm{z}$ koniecznością utrzymania niskiej temperatury skroplonego wodoru wynoszącej $-253 \mu \mathrm{C}$. Izolacja cieplna zbiornika musi być skonstruowana tak, aby uniemożliwić przekazywanie ciepła do wewnątrz zbiornika. W celu zmniejszenia strat ciepła stosuje się również dodatkową izolację w postaci ekranów termicznych umieszczonych pomiędzy ciepłą a zimna ścianką zbiornika $\mathrm{z}$ wodorem. Przy zastosowaniu wodoru w stanie ciekłym masa instalacji paliwowej jest porównywalna z masą instalacji zasilanej benzyną czy olejem napędowym, jednak objętość zbiornika jest kilkakrotnie większa. Ponadto pojazd zasilany ciekłym paliwem wodorowym powinien być przechowywany w pomieszczeniu posiadającym wentylację, co związane jest $\mathrm{z}$ tym, że wodór paruje $z$ intensywnością mniej więcej $2 \%$ na dobę.

\abela nr 4 zawiera porównanie parametrów układu paliwowego w przypadku zasilania benzyną oraz wodorem magazynowanym w różny sposób. 
Tabela 4. Porównanie parametrów układu paliwowego w przypadku zasilania benzynq oraz wodorem magazynowanym w różny sposób

\begin{tabular}{|c|l|c|c|c|c|c|}
\hline Lp. & Parametr & Benzyna & $\begin{array}{c}\text { Wodór } \\
\text { sprężony }\end{array}$ & $\begin{array}{c}\text { Wodór } \\
\text { skroplony }\end{array}$ & $\begin{array}{c}\text { Wodorek } \\
\mathbf{M g H}^{\mathbf{2}}\end{array}$ & $\begin{array}{c}\text { Wodorek } \\
\mathbf{F e T i H}^{2}\end{array}$ \\
\hline 1 & Masa paliwa, $\mathrm{kg}$ & 53,5 & 13,4 & 13,4 & 181 & 744 \\
\hline 2 & Objętość paliwa, $\mathrm{m}^{3}$ & 0,07 & 1,0 & 0,19 & 0,2 & 0,14 \\
\hline 3 & Masa zbiornika, kg & 13 & 1361 & 181 & 46 & 200 \\
\hline 4 & Objętość zbiornika, $\mathrm{m}^{3}$ & 0,08 & 1,53 & 0,28 & 0,23 & 0,16 \\
\hline 5 & $\begin{array}{l}\text { Całkowita masa układu } \\
\text { paliwowego, kg }\end{array}$ & 66,5 & 1374,4 & 194,4 & 227 & 944 \\
\hline
\end{tabular}

Wyróżnia się cztery sposoby zasilania silników wodorem:

- zasilanie gaźnikowe;

- wtrysk wodoru do układu paliwowego;

- wtrysk do kanału dolotowego przed zaworem ssącym;

- wtrysk bezpośredni do komory spalania.

Najłatwiejszym sposobem zasilania wodorem silnika spalinowego jest zasilanie gaźnikowe, zaś najbardziej skomplikowany jest system wtrysku bezpośredniego do komory spalania. System wtrysku bezpośredniego jest również najkorzystniejszy ze względu na to, że pozwala na całkowite wyeliminowanie zjawiska cofania się płomienia do układu dolotowego oraz przedwczesnego zapłonu.

Rys. 2. Przestawia zasadę działania samochodu zasianego wodorem.

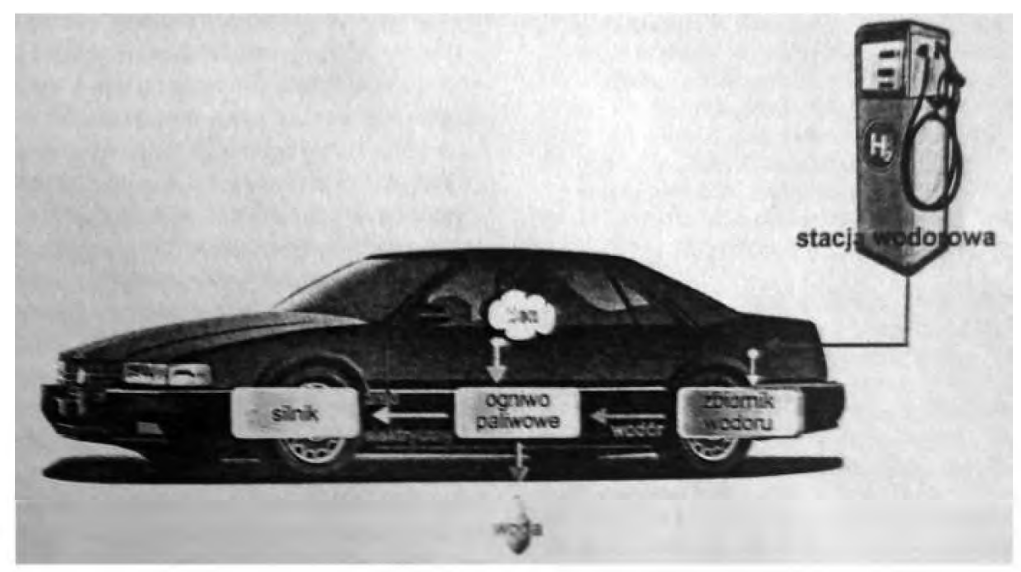

Rys. 2. Zasada dzialania samochodu zasilanego wodorem

Jednak dzięki intensywnym badaniom oraz wysokim nakładom finansowym na rozwój technologii wodorowych można już zobaczyć samochody napędzane wodorem między innymi takich marek, jak BMW, Mercedes czy Honda. 
W 2007 roku BMW wprowadziło pojazd napędzany wodorem z serii 7 Hydrogen (rysunek 3). Wyposażony jest w wewnętrzny dwucylindrowy silnik, który może być zasilany zarówno wodorem jak i benzyną. Silnik posiada moc 260KM i przyśpiesza od 0 do $100 \mathrm{~km} / \mathrm{h}$ w 9,5 sekundy. Prędkość maksymalna ogranicza jest elektronicznie do $230 \mathrm{~km} / \mathrm{h}$. Nowe WMW objęte jest projektem, dzięki któremu testowane jest funkcjonowanie samochodu napędzanego wodorem w warunkach praktycznych.

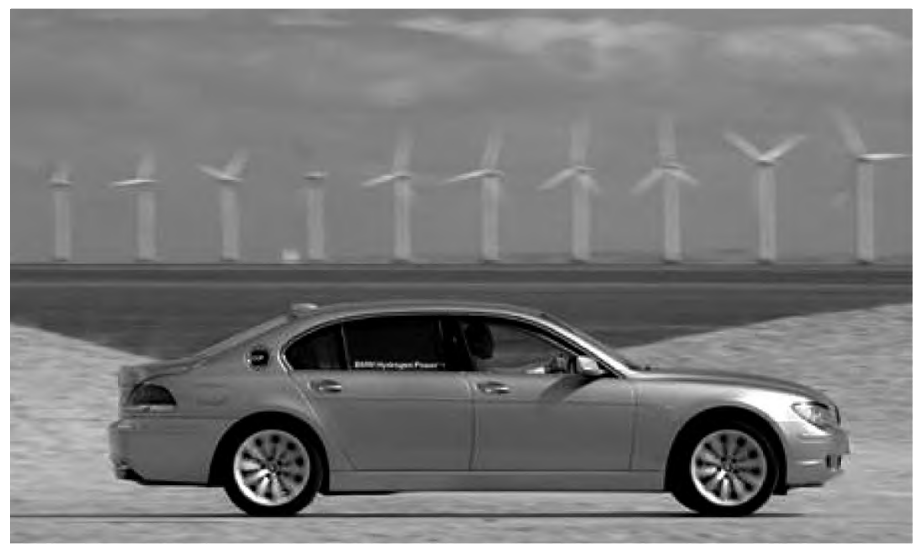

Rys. 3. BMW serii 7 Hydrogen

Niekwestionowana zaletą samochodu BMW z serii 7 Hydrogen jest brak emisji substancji szkodliwych spalin, szczególnie dwutlenku węgla. Jedynymi produktami spalania wodoru jest woda, dzięki czemu pojazd ten jest w pelni ekologiczny i przyjazny środowisku.

W związku z rozwojem technologii wytwarzania, magazynowania i transportowania wodoru oraz powstaniem pierwszych samochodów zasilanych wodorem powstała konieczność zbudowania stacji, na których będzie możliwość tankowania wodoru. Pierwsze takie stacje powstały już w Berlinie, Islandii czy Chinach.

Islandzka stacja $\mathrm{z}$ wodorem działa już od czterech lat. Jest ona przejawem strategii politycznej Islandii, która zakłada, że do w ciągu czterdziestu najbliższych lat kraj ten uniezależni się od paliw kopalnych. Przewiduje się, że w 2009 r. po drogach Islandii będzie jeździć ok. czterdziestu pojazdów napędzanych wodorem.

Największa stacja oferująca wodór została otwarta w stolicy Niemiec, Berlinie (rysunek 4). Klienci tej stacji, oprócz benzyny i oleju napędowego mogą zatankować również wodór w postaci ciekłej lub gazowej. Stacja ta ma na celu przetestowanie funkcjonowania tego typu stacji w warunkach praktycznych na 16 pojazdach napędzanych wodorem, w tym modelu HydroGen3. 


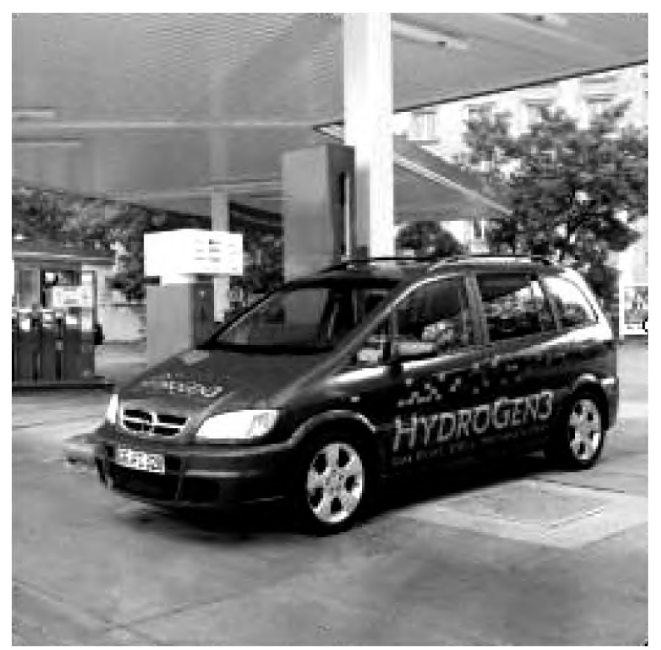

Rys. 4. Stacja w Berlinie z możliwościa tankowanie wodoru

Niekwestionowaną i zarazem największą zaletą silników zasilanych wodorem jest dużo mniejsza emisja substancji toksycznych w porównaniu do silników zasilanych benzyną. Emisja takich substancji, jak tlenki i ditlenki węgla, węglowodory oraz tlenki siarki dla silników zasilanych wodorem jest niekiedy nawet zerowa (tabela 5) zagrożenia, gdyż jest on nietoksyczny i nie powoduje zanieczyszczenia środowiska.

Tabela 5. Porównanie emisji substancji toksycznych pojazdów zasilanych benzyna oraz wodorem w odniesieniu do limitów emisji spalin

\begin{tabular}{|c|c|c|c|c|c|}
\hline \multirow{2}{*}{ Pojazdy } & \multirow{2}{*}{ Paliwo } & \multicolumn{4}{|c|}{ Emisja drogowa } \\
\hline & & $\mathrm{NO}_{x}$ & $\mathrm{CO}$ & $\mathrm{HC}$ & $\mathrm{CO}_{2}$ \\
\hline $\begin{array}{l}\text { Dodge D-50 } \\
\text { pick - up }\end{array}$ & $\mathrm{CH}_{2}$ & 1,19 [g/mila] & $0,44[\mathrm{~g} / \mathrm{mila}]$ & $0,26[\mathrm{~g} / \mathrm{mila}]$ & $8,66[\mathrm{~g} / \mathrm{mila}]$ \\
\hline $\begin{array}{l}\text { Mercedes MB } \\
310 \text { van }\end{array}$ & $\begin{array}{c}\mathrm{MeH}_{2} \text { (wodorki } \\
\text { metali) }\end{array}$ & $1,40[\mathrm{~g} / \mathrm{mila}]$ & $0,29[\mathrm{~g} / \mathrm{mila}]$ & $0,10[\mathrm{~g} / \mathrm{mila}]$ & $8[\mathrm{~g} / \mathrm{mila}]$ \\
\hline $\begin{array}{l}\text { BMW 745i, } \\
\text { 6-cyl. }\end{array}$ & $\begin{array}{c}\mathrm{LH}_{2} \text { (skroplony } \\
\text { wodór) }\end{array}$ & $0,31[\mathrm{~g} / \mathrm{km}]$ & 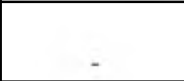 & (n) & 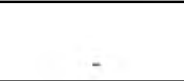 \\
\hline $\begin{array}{l}\text { BMW 745i, } \\
\text { 6-cyl. }\end{array}$ & benzyna & $2,50[\mathrm{~g} / \mathrm{km}]$ & - & - & - \\
\hline $\begin{array}{l}\text { UCR Ford } \\
\text { Tanger } \\
\end{array}$ & $\mathrm{CH}_{2}$ & 0,23 [g/mila] & $0,00[\mathrm{~g} / \mathrm{mila}]$ & $0,00[\mathrm{~g} / \mathrm{mila}]$ & $1,88[\mathrm{~g} / \mathrm{mila}]$ \\
\hline Mazda Miata & $\begin{array}{l}\mathrm{MeH}_{2} \text { (wodorki } \\
\text { metali) }\end{array}$ & $0,08[\mathrm{~g} / \mathrm{mila}]$ & $0,04[\mathrm{~g} / \mathrm{mila}]$ & $0,01[\mathrm{~g} / \mathrm{mila}]$ & - \\
\hline
\end{tabular}




\begin{tabular}{|l|c|c|c|c|c|}
\hline \multicolumn{7}{|c|}{ Limity emisji drogowej wg norm: } \\
\hline Federal Tier 1 & benzyna & $0,25[\mathrm{~g} / \mathrm{mila}]$ & $2,11[\mathrm{~g} / \mathrm{mila}]$ & $0,02[\mathrm{~g} / \mathrm{mila}]$ & - \\
\hline Euro 4 & benzyna & $0,08[\mathrm{~g} / \mathrm{km}]$ & $1,00[\mathrm{~g} / \mathrm{km}]$ & $0,10[\mathrm{~g} / \mathrm{km}]$ & $120[\mathrm{~g} / \mathrm{km}]$ \\
\hline $\begin{array}{l}\text { Kalifornia } \\
\text { ULEV (pojaz- } \\
\begin{array}{l}\text { dy o skrajni } \\
\text { niskiej emisji) }\end{array}\end{array}$ & - & $0,12[\mathrm{~g} / \mathrm{mila}]$ & $1,05[\mathrm{~g} / \mathrm{mila}]$ & $0,02[\mathrm{~g} / \mathrm{mila}]$ & - \\
\hline
\end{tabular}

Porównując emisję substancji toksycznych z silników autobusów zasilanych wodorem i gazem ziemnym oraz ON również wynika, że zdecydowanie korzystniejsze ze względów środowiskowych jest stosowanie wodoru jako paliwa silnikowego (tabela 6).

Tabela 6. Emisja substancji toksycznych z silników autobusów zasilanych wodorem oraz CNG $i$ ON

\begin{tabular}{|c|c|c|c|c|c|c|}
\hline \multirow{2}{*}{$\begin{array}{l}\text { Składniki } \\
\text { toksyczne }\end{array}$} & \multicolumn{3}{|c|}{ Wartość emisji [g/kWh] } & \multicolumn{3}{|c|}{ Europejskie normy } \\
\hline & $\begin{array}{l}\text { MAN } \\
\text { Diesel } \\
\end{array}$ & MAN CNG & $\begin{array}{c}\text { MAN silniki } \\
\mathrm{H} 2866 / \mathrm{H} 2876\end{array}$ & Euro III & Euro IV & Euro V \\
\hline tlenki azotu & 8,01 & 0,94 & 0,2 & 5,0 & 3,5 & 2,0 \\
\hline tlenki węgla & 1,01 & 1,12 & - & 2,1 & 1,5 & 0,02 \\
\hline węglowodory & 0,33 & 0,16 & 0,04 & 0,66 & 0,46 & 0,46 \\
\hline cząstki stałe & 0,25 & $<0,05$ & 0,005 & 0,01 & 0,02 & 0,02 \\
\hline
\end{tabular}

Silnik wodorowy będący w dobrym stanie technicznym oraz odpowiednio wyregulowany emituje jedynie wodę i tlenki azotu. Ograniczenie ilości tlenków azotu $w$ spalinach można uzyskać między innymi poprzez obniżenie temperatury w komorze spalania. Jeżeli jednak silnik jest w złym stanie technicznym, to dodatkowo w spalinach może pojawić się niewielka ilość nadtlenku wodoru. W gazach wylotowych silnika zasilanego wodorem może znajdować się również sam wodór. Pojawienie się tego gazu w spalinach nie stanowi jednak żadnego zagrożenia, gdyż jest on nietoksyczny i nie powoduje zanieczyszczenia środowiska. 


\section{Wnioski}

Pomimo wszystkich, niekwestionowanych zalet wodoru jako paliwa samochodowego droga do powszechnego zastosowania tego gazu jest jeszcze długa. Wiąże się to przede wszystkim z wysokimi cenami produkcji, magazynowania i dystrybucji tego gazu oraz koniecznością stworzenia całej infrastruktury wodorowej od podstaw. Powszechne zastosowanie wodoru jest jednak kwestią czasu, gdyż zasoby kopalnych źródeł energii ulegają wyczerpaniu i pojawia się potrzeba znalezienia nowych nośników energii. Wodór znakomicie nadaje się do tego celu, gdyż jest najbardziej rozpowszechnionym pierwiastkiem na kuli ziemskiej, poza tym podczas procesu jego spalania nie emitowanie są szkodliwe substancje. Gaz ten w niedalekiej przyszłości może zastąpić alternatywne źródła energii takie, jak węgiel kamienny czy ropa naftowa i stać się jednym z podstawowych źródeł energii zapewniając nam w przyszłości bezpieczeństwo energetyczne.

\section{LIDERA囚URA}

Сıок Z., Ochrona środowiska w elektroenergetyce. Podstawowe problemy wspótczesnej techniki, WKi冈, Warszawa 2002,

DAKowsKi M., WIĄcKowski S., O energetyce dla użytkowników oraz sceptyków, WN冈, Warszawa 2005 ,

H. FigIEL., PAJA A., Wodór w zwiąkach międzymetalicznych typu faz Lavesa ziem rzadkich z manganem, Przemysł Chemiczny 2005, 84, nr 11,

Gardziński W., Molenda J., Przemysł Chemiczny 2005, 84, nr 11,

Huczko A., Magazynowanie wodoru w fulerenach i nanorurkach weglowych, Przemysł Chemiczny $2002,81, \mathrm{nr} 1$,

JastrzęBska G., Odnawialne źródta energii i pojazdy proekologiczne, WN冈, Warszawa 2007, JęDrzejowska-Cicińska M., Kozak K., Krzemieniewski M., Energia i ekologia, 2007, nr 4,

KiJeŃski J., Chemik 2007, nr 1,

KiJeński J., Dlaczego wodór?, Przemysł Chemiczny 2005, 84, nr 11,

LeWandowski W., Proekologiczne odnawialne źródła energii, WND, Warszawa 2007,

LublińsKa K., ZaGórski A., Spychalski W., KurzydŁowski K.J., Tworzywa konstrukcyjne w technologiach wodorowych, Przemysł Chemiczny 2005, 84, nr 11,

Mianowski A., \okarska A., Przemysł Chemiczny 2005, 84, nr

Molenda J., Gaz ziemny. Paliwo i surowiec, WND, Warszawa 1994,

Narkiewicz U., Ekiert E., Arabczyk W., Przemysł Chemiczny 2007, 86, nr 9,

NOWACKI J.P., Wodor - nowy wektor energii, PWN, Warszawa 1966,

Zielińsii J., Urbaniec K., Machowska Z., Przemysł Chemiczny 2007, 86, nr 12,

www.ekoenergia.pl,

www.bmwauto.net.pl,

www.autocentrum.pl,

www.moto.wp.pl,

www.infobus.com.pl,

www.flota.com.pl,

www.auto-moto.pl,

www.ndtest.com.pl,

www.gigawat.net.pl. 


\section{Hydrogen - fuel future}

\section{SUMMARY}

Hydrogen it one of most spread radical on earth. This gas has to become alternative due to so general occurrence for mineral fuels exactly chance. Low is unchallenged advantage of employment of hydrogen in car engines emission, then hydrogen is fuel ecological completely. On way to general employment of hydrogen biggest barrier stagnant as storage of this gas is fuel and high cost of its production.

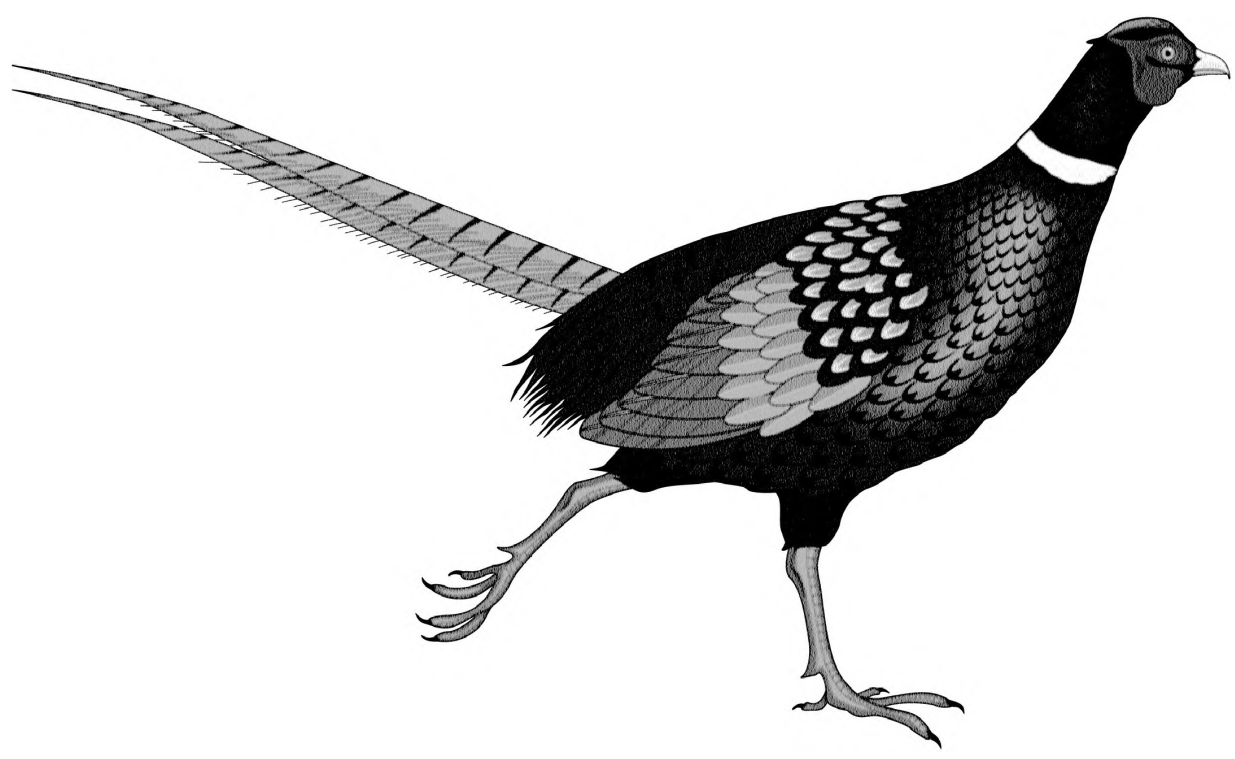

